\title{
The Complexity of Child Development and the Importance of a Broader Approach. A Girl with a Loss of Verbal Language: A Case Report
}

\section{Esteban Rowensztein*}

Children's Hospital "Dr. Ricardo Gutiérrez" - Argentine Society of Pediatrics, Texas, USA

*Corresponding Author: Esteban Rowensztein, Children's Hospital “Dr. Ricardo Gutiérrez” - Argentine Society of Pediatrics, Texas, USA.

Received: September 23, 2019; Published: October 10, 2019

DOI: 10.31080/ASMS.2019.03.0433

\begin{abstract}
Development conception shared by members of the health team and the epistemic framework in which their clinical practice is framed, strongly determine both the diagnostic strategy and the therapeutic interventions.

Biomedical discipline generally conceives human development as a maturation process, with a strong biological and genetic determination. By their part, other disciplines take subjective and social aspects into consideration. Markedly biological approaches take the risk of leaving out important contextual factors.

M. is now a 3-year-old girl. Her brother has Autism Spectrum Disorder. Development was according to her age until she was 19 month-old, when she showed loss of verbal language and behavior disorders.

Neurological evaluation and electroencephalogram were normal. Phonoaudiological evaluation demonstrates adequate comprehension for her age. Regarding the expressive aspect, she only uttered "mm". As warning signs she showed loss of words that her mother stated she used to say before, and strong tantrums.

During interviews, her mother reported that the symptoms began after the girl had witnessed gender-based violence situations at home. Social Service was reported. Then, the girl started early care and speech therapy and had shown a good clinical response.
\end{abstract} Keywords: Child Development; Loss of Verbal Language; Interdiscipline; Pediatrics

\section{Introduction}

Development conception shared by members of the health team and the epistemic framework in which their clinical practice is framed, strongly determine both the diagnostic strategy and the therapeutic interventions. Biomedical discipline generally conceives human development as a maturation process, with a strong biological and genetic determination. By their part, other disciplines -especially in the area of mental health- take subjective and social aspects into consideration. Markedly biological approaches take the risk of leaving out important contextual factors when dealing with these issues [1-3].

The aim of this article is to reflect on the need for understanding the different factors that influence child development from an interdisciplinary approach. Based on a case report, I attempt to show the relevance of a broader approach that includes the pediatrician working together with other health professionals $[4,5]$.

\section{Case Report}

M. is now a 3-year-old girl with no perinatological background. As she had suffered from urinary infection when being 9 months old, she had to undergo periodical hospital checkups which she attended irregularly. Furthermore, she had a brother with language, communication and behavioral disorder. The ADOS 2 and Vinelad tests had been performed and he had been diagnosed with Autism Spectrum Disorder (ASD) by the neurologists.

M. had a typical development until she was 19 months old. Then, she showed loss of verbal language and began to have behavioral 
problems. Evaluations by neurologists, mental health specialists and speech therapy were requested.

The neurological evaluation was normal, with normal sleep electroencephalogram with photo stimulation.

Mental health evaluation: it was started, but it could never be completed due to logistical problems.

The phonoaudiological evaluation reported an adequate understanding for her age, but she only uttered "mm"; and she did not imitate words or greetings. As warning signs, she showed loss of verbal language that her mother stated she used to say before, and some strong tantrums. Speech therapy was prescribed.

In a situation like this, the following differential diagnoses [6] must be considered:

- Within the group of acquired Aphasias: stroke, central nervous system infections or traumatic brain injury. They usually appear together with other symptoms that make their cause evident.

The Landau-Kleffner syndrome or acquired epileptic aphasia associates loss of language, a characteristic pattern in the EEG and, sometimes, epileptic seizures.

- $\quad$ Autistic regression: $30 \%$ of children with ASD show a loss of linguistic abilities.

- $\quad$ Rett syndrome

- Childhood disintegrative disorder

- $\quad$ Degenerative diseases

- $\quad$ Selective mutism

At the time of the consultation the girl showed almost absolute absence of words in all areas of her life, with good communicative intention. The only sound uttered was "mmm", the understanding was preserved; protoimperative gesture, protodeclarative and joint attention were present. She made herself understood through gestures. There had been no significant changes in the social aspect, except for the fact that she had more frequent and intense tantrums than usual.

M's family lived in a house located in the suburbs of Buenos Aires city. There, her 32-year-old mother, a housewife, originally born in an Argentine province, who had no family or friends in Buenos Aires city, lived together with her 35-year-old father, who worked as a cab driver, and their 3 and 5 year-old children.
Within the framework of an interview during a pediatric checkup, M's mother reported that the symptomatology had begun a few days after the girl had witnessed situations of gender violence, both physical and verbal, that took place at home. Moreover, she linked the current situation with another similar episode that happened when she was pregnant with $\mathrm{M}$, and her son witnessed some situations of physical violence towards her. After that, her son who was 22 month- old and was apparently healthy, stopped talking and began having the symptoms he shows at present.

In that interview, some other issues came up: they all slept in the same bed, her mother kept breastfeeding her frequently until that moment, her father did not participate in issues related to parenting, and there was an absolute dependence on the father both in the economic aspect and also in relation to the possibility of taking the children to any other place.

Social Service was informed about the situation. The girl was attending speech therapy near her house, without having showed any changes in the symptoms. She never managed to complete the mental health assessment in Buenos Aires for logistical reasons. However, it was possible to contact an Early Care specialist who worked near her home, who conducted an evaluation and began a treatment with the girl and the family. M continued undergoing speech therapy and her parents began to attend some family orientation counseling, thanks to the networks that were established through the local Social Service.

After three months of therapies, M gradually began to speak again and construct sentences, while the tantrums started easing up. At the time of the last consultation, no situations of physical or verbal violence had repeated. Family relationships were improving. In the last control she attended, one year after starting the interventions, M presented a language according to her age, without difficulties in any other areas. She now continues in clinical follow-up.

\section{Conclusion}

Given the complexity of the child development process, the pediatric approach to their problems requires a broad perspective that contemplates the different factors - biological, emotional, subjective, and social - that influence it [7].

Markedly biological approaches take the risk of leaving out, as in this example, important contextual factors, which -in many situations- are decisive when considering these problems. 
To understand children's developmental problems from a comprehensive approach requires to be able to think of a boy or a girl as a single subject, immersed in a relational network, in a specific social, economic, political and cultural context $[5,8]$. It implies to consider that the person who he/she is at that moment is a result of a complex interaction of his/her genes with that environment in which he/she was and is immersed, and of the experiences that he/she has lived and is still living [1].

Considering their subjectivity as a process in constant construction determined by multiple variables and not as something given, allows us to think about them from the complexity, so as not to fall into simplifications, generalizations or reductionisms [1].

Finally, knowledge about early childhood development should always be multidimensional and interdisciplinary. It implies that dealing with these problems in the most comprehensive way possible, requires the perspectives from different disciplines working together $[9,10]$.

\section{Bibliography}

1. Rowensztein E and Kremenchuzky JR. "Pediatría, Desarrollo Infantil e Interdisciplina”. Buenos Aires: Noveduc (2019): 13.

2. Madrid LB. Realizando "diagnósticos diferenciales" de los modelos teóricos del proceso salud- enfermedad". Kairos: Revista de temas sociales (2011): 6-13.

3. Taussig Michael. "La reificación y la conciencia del paciente". En: Un gigante en convulsiones. Ed. Gedisa, Barcelona (1995).

4. Escardó F. "Qué es la pediatría”. 1ra edición. Buenos Aires: Fundación Sociedad Argentina de Pediatría (2007): 7-11.

5. Menéndez E. De sujetos, saberes y estructuras. Introducción al enfoque relacional en el estudio de la salud colectiva. Buenos Aires: Lugar Editorial (2009).

6. Artigas J., et al. "Trastornos del lenguaje. Protocolos Diagnóstico Terapeúticos de la AEP. Neurología Pediátrica. Asociación Española de Pediatría. Sociedad Española de Neurología Pediátrica. 2da edición. España (2008): 178-184.

7. Engel GL. "The need for a new medical model: a challenge for biomedicine". Science 196 (1977): 129-136.

8. Hertzman Clyde. "Social Geography of Developmental Health in the Early Years". Healthcare Quarterly 13 (2010).
9. Shonkoff J. Phillips, DA (Org.) From Neurons to neighborhood. The Science of Early Childhood Development. National Research Council, Institute of Medicine, de los EEUU. Washington: National Academy Press (2000).

10. Maciel F. "Lo posible y lo imposible en la interdisciplina". Revista de L'Associació Catalana D’Atenció Precoç (2001).

\section{Volume 3 Issue 11 November 2019}

(c) All rights are reserved by Esteban Rowensztein., et al. 